\title{
The effect of clinoptilolite on long bone morphometry in Japanese quail (Coturnix coturnix japonica)
}

\author{
Yasin Demiraslan ${ }^{1}$, Tuncay Tufan ${ }^{2}$, Mehmet Sari $^{3}$, Yalcin Akbulut ${ }^{4}$, Mustafa Orhun Dayan ${ }^{5, *}$, \\ Abdulsamed Kukurt ${ }^{6}$ \\ ${ }^{1}$ Department of Anatomy, Faculty of Veterinary Medicine, Mehmet Akif Ersoy University, Burdur, Turkey \\ ${ }^{2}$ Department of Animal Nutrition and Nutritional Diseases, Faculty of Veterinary Medicine, Kafkas University, Kars, Turkey \\ ${ }^{3}$ Department of Animal Science, Faculty of Veterinary Medicine, Mehmet Akif Ersoy University, Burdur, Turkey \\ ${ }^{4}$ Kars College of Health, Kafkas University, Kars, Turkey \\ ${ }^{5}$ Department of Anatomy, Faculty of Veterinary Medicine, Selcuk University, Konya, Turkey \\ ${ }^{6}$ Department of Biochemistry, Faculty of Veterinary Medicine, Kafkas University, Kars, Turkey
}

Email address:

modayan@selcuk.edu.tr (M. O. Dayan)

\section{To cite this article:}

Yasin Demiraslan, Tuncay Tufan, Mehmet Sari, Yalcin Akbulut, Mustafa Orhun Dayan, Abdulsamed Kukurt. The Effect of Clinoptilolite on Long Bone Morphometry in Japanese Quail (Coturnix coturnix japonica). Animal and Veterinary Sciences. Vol. 2, No. 6, 2014 , pp. 179-183. doi: $10.11648 /$ j.avs.20140206.14

\begin{abstract}
This study was aimed to investigate the effect of clinoptilolite long bone morphometry in Japanese quail. In the study, 100 female Japanese quails were used. The animals were slaughtered in 42nd day of study. The long bones of the animals were macerated by boiling. Twenty-three values were measured from the bones. Consequently, it was determined that the addition of clinoptilolite to feed ration in various ratios caused some statistical changes in the morphometry of long bones. The reason of this case is considered as high silicate ingredient available in clinoptilolite.
\end{abstract}

Keywords: Bone, Japanese quail, Morphometry, Silicon, Zeolite

\section{Introduction}

Zeolites have a broad usage as feed additive in nutrition of livestock. Zeolites are natural compounds comprised of volcanic, phanerocrystalline, lightweight, homogeneous, aluminium silicate; and they contain alkali and rare territorial elements such as $\mathrm{Na}, \mathrm{K}, \mathrm{Ca}, \mathrm{Mg}$, Si [1-4]. These materials are used in the industry of water purification, in building and medicine fields, artificial fertilizer production and animal feeding as feed additive [5,6]. In the environment, 50 types of natural and more than 200 syntactic zeolite have been identified. Clinoptilolite is among the natural zeolites not involving harmful elements, having high quality, and used in the animal feeding as feed additive [7]. There are many studies in the literature concerning the evaluation of certain criteria such as egg yield, egg weight, and quality of egg shell, stools quality, and feed consumption by adding zeolites to ration [8-12]. However, any study was not found in the literature search subjecting the effect of clinoptilolite, used in the sector of livestock commonly, on long bone morphometry in quails used as laboratory animals. For this reason, this study aimed to investigate the effect of clinoptilolite addition to extent of $\% 2,4,6$ to long bone morphometry.

\section{Materials and Methods}

100 female Japanese quails (Coturnix coturnix japonica), in their one day age, were used. The quails were randomly distributed into four groups each of which involving 25 quails. Quails were fed with mixed feed, prepared in line with the norms offered by NRC [13] of which compound and food substance ingredient is given in Table 1 , in their beginning (0-3 weeks) and end (4-6 weeks). Japanese quails in the groups (Control-C) were fed with the mixed feed during the research, other groups were fed with same feed by adding them 2\% (Experimental I- EI), 4\% (Experimental IIEII) and 6\% (Experimental III- EIII). The ingredient of the clinoptilolite (Aegean Zeolite Industry, Balikesir), used in the study, was given in Table 2. The conditions of illumination, water, ventilation and other conditions of trial and control groups were standardised during the study carried out in cage environment. 
The animals were slaughtered to protect the quality of carcases' edibleness in 42nd day of study. Serum calcium (Ca), phosphorus (P) and alkaline phosphatase (ALP) levels were determined by taking blood samples from animals during the slaughter.

The long bones (humerus, radius, ulna, femur and tibia) of the animals, whose carcases' were taken, were macerated by boiling. The bones were photographed (Canon 600D) for morphometric measurements. Required measurements were obtained in the programme of Image $\mathrm{J}$ by transferring photos to computer. These measurements were determined as following; HL; length of humerus, HPW; proximal width of humerus, HDW; distal width of humerus, HSW; smallest width of humerus, RL; length of radius, RPW; proximal width of radius, RDW; distal width of radius, RSW; smallest width of radius, UL; length of ulna, UPW; proximal width of ulna, UDW; distal width of ulna, USW; smallest width of ulna, FL1; 1th length of femur, FL2; 2nd length of femur, FPW; proximal width of femur, FDW; distal width of femur, FSW; smallest width of femur, FCL; length of condylus femoris, FTL; length of trochlea ossis femoris, TL1; 1th length of tibia, TL2; 2nd length of tibia, TPW; proximal width of tibia and TDW; distal width of tibia. Driesch [14] was referenced for measurements.

Table 1. Composition and nutrient ingredients of mixed feeds used in the study, \%

\begin{tabular}{lll}
\hline Feeding Materials & Beginning Feed & Nutruring Feed \\
\hline Corn & 34.00 & 38.00 \\
Wheat & 15.70 & 14.70 \\
Vegetable Oil & 3.53 & 3.65 \\
Soya Bean Cake & 25.00 & 12.00 \\
Cotton Seed Cake & 18.51 & 15.51 \\
Sunflower Cake & - & 13.00 \\
DCP & 0.94 & 0.94 \\
Lime Stone & 1.10 & 1.10 \\
Vit. Min. mixing* & 0.35 & 0.35 \\
Salt & 0.30 & 0.30 \\
DL-Metionin & 0.20 & 0.08 \\
L-Lizin & 0.09 & 0.09 \\
L-Tryptophan & 0.08 & 0.08 \\
Bicarbonate of Soda & 0.20 & 0.20 \\
Feeding Material Ingredient, on the basis of KM & \\
Dry Material & 91.70 & 92.50 \\
Metabolic Energy, kcal/kg** & 2962 & 2896 \\
Raw protein, \% & 22.10 & 20.02 \\
Raw Oil, \% & 6.57 & 5.12 \\
Raw cellulose, \% & 5.28 & 7.52 \\
Raw Ash, \% & 4.28 & 6.60 \\
\hline
\end{tabular}

*Vitamin Mineral Mixing: In each 2,5 kg'; Vit A: 6000000 IU, Vit D3: 32000000 IU, Vit E: $40000 \mathrm{mg}$, Vit $\mathrm{K}_{3}: 1600 \mathrm{mg}$, Vit $\mathrm{B}_{1}: 1200 \mathrm{mg}$, Vit $\mathrm{B}_{2}$ : $3200 \mathrm{mg}$, Niacin: $24000 \mathrm{mg}$, Cal.D-Pantotenat: $7200 \mathrm{mg}$, Vit $B_{6}: 2000 \mathrm{mg}$, Vit $B_{12}: 6,4 \mathrm{mg}$, D-Biotin: $80 \mathrm{mg}$, Folic Asid: $800 \mathrm{mg}$, Vit C: $40000 \mathrm{mg}$, Mangan: $42000 \mathrm{mg}$, Iron: $33600 \mathrm{mg}$, Zinc: $33600 \mathrm{mg}$, Copper: $3600 \mathrm{mg}$, Cobalt: $80 \mathrm{mg}$, Iodine: $400 \mathrm{mg}$, Selenium: $72 \mathrm{mg}$, Molibden: $416 \mathrm{mg}$.

**: found by means of calculation.
Table 2. Chemical properties of the clinoptilolite used in this study, \%

\begin{tabular}{ll}
\hline Parameters & Ratio \\
\hline $\mathrm{SiO}_{2}$ & 69.20 \\
$\mathrm{Al}_{2} \mathrm{O}_{3}$ & 10.81 \\
$\mathrm{TiO}_{2}$ & 0.08 \\
$\mathrm{Fe}_{2} \mathrm{O}_{3}$ & 1.18 \\
$\mathrm{Na}_{2} \mathrm{O}$ & 0.37 \\
$\mathrm{~K}_{2} \mathrm{O}$ & 2.78 \\
$\mathrm{CaO}$ & 2.98 \\
$\mathrm{MgO}$ & 1.48 \\
$\mathrm{P}_{2} \mathrm{O}_{5}$ & 0.02 \\
$\mathrm{SO}$ & 0.04 \\
$\mathrm{Raw}_{3}$ material $\left(1050{ }^{\circ} \mathrm{C}\right)$ & 10.21 \\
$\mathrm{pH}$ & 7.00 \\
\hline
\end{tabular}

SPSS (20.0 version) was used for mean, standard deviation and $p$ values of obtained values in the study. Tukey test was performed in the comparison process of groups. The ingredients of feeds, used in test, was determined according to the methods reported in AOAC [15].

In this study, Nomina Anatomica Avium [16] was referenced for terminology related to anatomy.

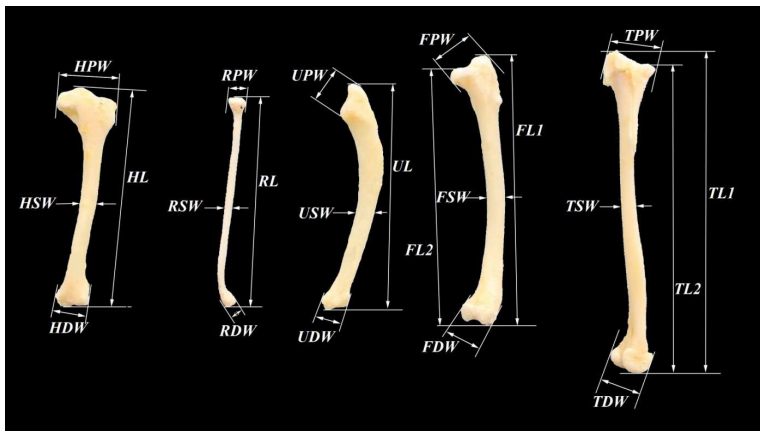

Figure 1. Measurement points of the long bones in the quail. To right from left; humerus, radius, ulna, femur and tibia.

\section{Results}

\subsection{Blood Analysis}

Mean and standard deviation values of $\mathrm{Ca}, \mathrm{P}$ and ALP belonging to control and test groups have been shown in Table 3. Therefore, any significant (statistical) difference was not found between the groups in terms of blood analysis results as of the slaughter day $(\mathrm{P}>0.05)$. However, a gradual increase of alkaline phosphate was detected in groups.

Table 3. Blood serum parameters of experimental groups.

\begin{tabular}{lllll}
\hline Parameter & C & EI & EII & EIII \\
\hline $\begin{array}{l}\text { Calcium } \\
(\mathrm{mg} / \mathrm{dL})\end{array}$ & $12.19 \pm 0.49$ & $13.52 \pm 0.74$ & $13.11 \pm 3.94$ & $12.53 \pm 0.66$ \\
$\begin{array}{l}\text { Phosphor } \\
(\mathrm{mg} / \mathrm{dL})\end{array}$ & $5.06 \pm 0.72$ & $4.97 \pm 0.23$ & $5.1 \pm 0.57$ & $5.39 \pm 0.71$ \\
ALP (IU/L) & $581.20 \pm 50.21$ & $642.03 \pm 60.53$ & $647.52 \pm 42.23$ & $730.42 \pm 74.13$ \\
\hline
\end{tabular}

\subsection{Morphometrical Findings}

Mean and standard deviation data, concerning the morphometry of long bones obtained in the research, was 
shown in Table 4. Therefore, it was determined that the addition of clinoptilolite to ration in various ratios caused some statistical changes in the morphometry of long bones. Although statistical significance was detected between control and experimental groups in terms of HL and HDW, it was observed that other measurements of humerus did not involve any statistical significance among other groups $(\mathrm{P}<0.05)$. It was deduced that there was statistical significance between $\mathrm{C}$ and EII groups concerning $\mathrm{RL}$ $(\mathrm{P}<0.05)$. On the other hand, it was resulted that the difference between control and experimental groups (I, II, III) was important in terms of RPW $(\mathrm{P}<0.05)$. When UL was considered, it was seen that the difference between control group and EII was significant $(\mathrm{P}<0.05)$. In addition, the study revealed that the values of FL1 and FPW related to femur were different among the groups. It was detected that the FL1 is different for $\mathrm{C}$ and EI, EII and this difference was statistically significant. Furthermore, it was established that there was significant difference between control group and EI, II, III and the difference between EIII and EI, EII in terms of FPW value $(\mathrm{P}<0.05)$. It was observed that data (particularly data belonging to tibia) beyond the reported values in the study are different, but they did not involve statistical significance $(\mathrm{P}>0.05)$.

Table 4. Bone measurements of experimental groups. A: Average. a $a$ : mean and standard deviation.

\begin{tabular}{llllll}
\hline & C & EI & EII & EIII & A \\
\hline HL* & $36.13 \pm 1.32$ & $38.63 \pm 0.87$ & $38.28 \pm 0.2$ & $37.38 \pm 1.12$ & $37.60 \pm 1.34$ \\
HPW & $3.25 \pm 0.34$ & $3.40 \pm 0.31$ & $3.36 \pm 0.21$ & $3.40 \pm 0.68$ & $3.35 \pm 0.39$ \\
HDW* & $1.68 \pm 0.26$ & $2.34 \pm 0.25$ & $2.39 \pm 0.10$ & $1.79 \pm 0.19$ & $2.05 \pm 0.38$ \\
HSW & $0.75 \pm 0.08$ & $0.73 \pm 0.04$ & $0.77 \pm 0.04$ & $0.72 \pm 0.07$ & $0.74 \pm 0.06$ \\
RL* & $28.12 \pm 0.60$ & $29.96 \pm 1.00$ & $29.12 \pm 0.60$ & $28.68 \pm 0.92$ & $28.97 \pm 1.01$ \\
RPW* & $1.10 \pm 0.15$ & $0.62 \pm 0.03$ & $0.73 \pm 0.19$ & $0.79 \pm 0.19$ & $0.81 \pm 0.23$ \\
RDW & $1.23 \pm 0.23$ & $1.18 \pm 0.14$ & $0.99 \pm 0.15$ & $0.98 \pm 0.29$ & $1.09 \pm 0.23$ \\
RSW & $0.35 \pm 0.05$ & $0.32 \pm 0.04$ & $0.39 \pm 0.09$ & $0.34 \pm 0.03$ & $0.35 \pm 0.06$ \\
UL* & $31.39 \pm 0.81$ & $33.90 \pm 1.19$ & $32.86 \pm 0.26$ & $32.85 \pm 1.08$ & $32.75 \pm 1.24$ \\
UPW & $3.61 \pm 0.35$ & $3.99 \pm 0.32$ & $4.01 \pm 0.21$ & $3.53 \pm 0.27$ & $3.79 \pm 0.35$ \\
UDW & $1.01 \pm 0.10$ & $1.16 \pm 0.11$ & $1.03 \pm 0.09$ & $1.25 \pm 0.24$ & $1.11 \pm 0.17$ \\
USW & $0.69 \pm 0.12$ & $0.67 \pm 0.06$ & $0.71 \pm 0.03$ & $0.70 \pm 0.07$ & $0.69 \pm 0.07$ \\
FL1 & $38.78 \pm 1.30$ & $40.84 \pm 0.65$ & $40.58 \pm 1.14$ & $41.45 \pm 1.18$ & $40.41 \pm 1.43$ \\
FL2 & $37.58 \pm 1.92$ & $39.28 \pm 0.84$ & $39.72 \pm 1.17$ & $39.47 \pm 0.95$ & $39.01 \pm 1.47$ \\
FPW & $3.62 \pm 0.46$ & $3.28 \pm 0.59$ & $2.83 \pm 0.43$ & $3.67 \pm 0.45$ & $3.35 \pm 0.56$ \\
FDW & $3.11 \pm 0.70$ & $2.53 \pm 0.50$ & $3.84 \pm 0.53$ & $2.18 \pm 0.13$ & $2.92 \pm 0.80$ \\
FSW & $0.83 \pm 0.11$ & $0.80 \pm 0.10$ & $0.82 \pm 0.06$ & $0.76 \pm 0.09$ & $0.80 \pm 0.09$ \\
FCL & $2.63 \pm 0.20$ & $3.01 \pm 0.23$ & $2.64 \pm 0.23$ & $2.76 \pm 0.23$ & $2.76 \pm 0.26$ \\
FTL & $4.34 \pm 0.43$ & $4.38 \pm 0.31$ & $4.91 \pm 0.43$ & $4.57 \pm 0.29$ & $4.55 \pm 0.41$ \\
TL1 & $50.25 \pm 1.66$ & $52.29 \pm 1.01$ & $51.58 \pm 0.96$ & $51.35 \pm 2.06$ & $51.37 \pm 1.56$ \\
TL2 & $48.46 \pm 1.90$ & $50.98 \pm 1.03$ & $50.55 \pm 0.85$ & $49.52 \pm 2.07$ & $49.88 \pm 1.74$ \\
TPW & $4.17 \pm 0.32$ & $3.30 \pm 0.76$ & $3.31 \pm 0.24$ & $3.41 \pm 0.74$ & $3.55 \pm 0.64$ \\
TDW & $1.55 \pm 0.16$ & $1.43 \pm 0.05$ & $1.45 \pm 0.14$ & $1.40 \pm 0.04$ & $1.46 \pm 0.12$ \\
\hline & & & & & \\
& & &
\end{tabular}

* : $\mathrm{P}<0.05$. The unit of the mean values and the standard deviations are $\mathrm{mm}$.

\section{Discussion}

Bone is an important factor indicating mineral condition in poultry diets. $\mathrm{Ca}$ and $\mathrm{P}$ forms inorganic structure of bone [17] $\mathrm{Ca}$ and $\mathrm{P}$ are required both in growing process of bone and new bone tissue formation [18]. For this reason, $\mathrm{Ca}$ and $\mathrm{P}$ are important indicators in following the bone development. In addition, ALP activity is used as an indicator in bone development $[19,20]$. The development of long bones is realised as a result of the differentiation and reproduction of chondrocytes in epiphyseal development plates [19]. The maturing of chondrocyte bring along osteoblastic activity. Mineralisation is seen finally in ossification. ALP is generated by osteoblasts during ossification [21,22]. In this study, $\mathrm{Ca}, \mathrm{P}$ and ALP serum values, playing active role in ossification, were determined. Accordingly, it was established that clinoptilolite, which was added in different levels to ration, did not affect statistically $\mathrm{Ca}, \mathrm{P}$ and ALP serum level in slaughter day. Nevertheless, it was observed that ALP level was in the lowest degree in control group while it increased in other groups in the parallel amount of added clinoptilolite. Safeikotuli et al. [23] reported in his study that zeolite, added to 15 and $30 \mathrm{~g} / \mathrm{kg}$, and relatively increased the ALP degree in broilers. Clinoptilolite, used in the study, is among the silicate compounds linked to each other via channels [2]. The decreasing effect directed to phosphor degree with aluminium and silisium ions in its structure influences the bone development positively [24,25]. Moreover, silicon affects the bone development in a positive way by suppressing the bone resolution, increasing trabecular bone volume [26], increasing ostreoblastic activity [27], and by reducing osteoclastic activity. It has been reported in the previous animal studies that inadequacy of silicon in diet cause defects in musculoskeletal [28-30]. Besides, it has been determined that silicon may be effective as mineral concentrator, thus being beneficial in bone development $[29,30]$. However, the studies done in recent years revealed that silicon is also effective beside $\mathrm{Ca}, \mathrm{P}$ and vitamin $\mathrm{D} 3$ in the development long bones [31-33]. It has been detected in this study that there is significant difference among the values of HL, HDW, RL, RPW, UL, FL1, FPW. It can be thought that these differences arise from the high silicate ingredient of clinoptilolite (69.20\%) with the data above mentioned.

Bone metabolism is affected by parathormone, calcitonin, growth hormone, oestrogen, glucocorticoids [34], and androgens [35]. Safaeikatouli et al. [23] reported that daily $15 \mathrm{~g} / \mathrm{kg}$ zeolite increased the level of growth hormone significantly in terms of statistics. Nevertheless, study did not evaluate to what extent different amount of zeolite addition would affect hormone levels, thus this may be regarded as one of the limitations of study.

The literature informs us that normal bone development is influenced by feeding factors, genetic, age and growth (lively weight increase) [36]. However, Neumann [37] stated that there is not any correlation between lively weight increase and bone development. In this study, these variables have been standardised as follows feeding factor with equal ration 
and ad-libitum water, by using genetic female Japanese quail, and by determining same hatching age and slaughter day.

Tibia is used as representator in general evaluations concerning the musculoskeletal of poultries [38-41]. It has been observed that there is no appeared statistical significant differences in long bone morphometric data apart from tibia. In this case, the usage of tibia as representative of skeleton system in related studies should be revised.

Related literature $[42,43]$ has reported that lengthen and development degree is not same in each part of long bones, and lengthen is more in epiphysis or proximal part than diaphysis. Growth plates in epiphysis or proximal parts of bone is responsible for lengthen and development. It realises this process by chondrocyte replication, cell maturation and mineralisation [42,43]. All of the statistical differences determined in the study among research groups are related to bone length and epiphysis part rather than diapheser part. This case shows to what extent different ratio zeolite addition to ration affected growth plates in different levels in that part.

This study has some limitations. These involve the periodical blood analysis of bone development (hormone level, enzyme activity, minerals) structural bone analysis (bone layer thickness, medullar caliber, and bone density).

Consequently, it has been determined in the study that clinoptilolite, added to ration in different amounts, affected to Japanese quail long bone morphometry to a certain extent. The reason of this case is considered as high silicate ingredient available in clinoptilolite. In addition to this result, we consider that the lengthen effect of clinoptilolite for bone length and body length should be investigated with different laboratory animals (rat, rabbit, dog) in a large scale.

\section{References}

[1] Ayvaz Z. 2004.The Raw Material of 21st Century: Zeolite. Ekoloji Magazin, 1

[2] Erener G and Saricicek BZ. 1995. The use of zeolite in poultry animal feeding. Teknik Tavukculuk Dergisi, 82, 18-22.

[3] Leung S. 2004. The Effect of Clinoptilolite Properties and Supplementation Levels on Swine Performance. Department of Bioresource Engineering, McGill University, PhD Thesis Montreal.

[4] Virta RL. 1998. Zeolites. Geological Survey Puplication. U.S., p: 4, 1998.

[5] Çolpan I., Yalçın S., Ergün A., Tuncer SD., Küçükersan K., Onol AG., Y1ld1z G. 1995. Studies on Zeolite Using in Animal Feeding. Marmara Region II. Animal Husbandry Congress, October 25-27, Bursa, Turkey.

[6] Yalcin S., Ergun A., Colpan I., Kucukersan K. 1987. The Effects of Zeolite on Laying Hens. Lalahan Hayvancilik Araştırma Enstitüsü Dergisi, 27, 28-49.

[7] Melenova L., Ciahotny K., Jirglova H., Kusa H., Ruzek P. 2003. Removal of ammonia from waste gas by means of adsorption on zeolites and their subsequent use in agriculture (in Czech). Chemicke Listy, 97, 562-568.
[8] Altan O., Cabuk M., Bozkurt M., Altan A., Ozkan K., Alcicek A. 1998. III. Effect of Zeolite on Performance, Egg Quality, Some Parameters of Tibia and Blood of Laying Hen. Ege Üniversitesi Ziraat Fakültesi Dergisi, 35, 25-32.

[9] Bozkurt M., Basmacioglu H., Alcicek A., Cabuk M. 2001. Effect of Natural Zeolite on Laying Hen Performance. Tavukculuk Arastırma Dergisi, 3, 8-11.

[10] Fethiere R., Miles RD., Harms RH. 1990. Influence of Synthetic Sodium Aluminosilicate on Laying Hens Fed Different Phosphorus Levels. Poultry Science, 69, 2195-8.

[11] Nakaue HS and Koelliker JK. 1981. Studies with clinoptilolite in poultry. 1. effect of feeding varying levels of clinoptilolite (zeolite) to dwarf single comb white leghorn pullets and ammonia production. Poultry Science. 60, 944-9.

[12] Ozturk E., Erener G., Sarica M. 1996. Influence of natural zeolite on performance of laying hens and egg quality. Turkish Journal of Agriculture Forestry. 22, 623-628.

[13] NRC. 1994. Nutrient Requirements of Poultry. 9th rev. ed. National Academy Press, Washington.

[14] Driesch A Von Den. 1976. A guide to the measurements of animal bones from Archaeological Sites. Harvard Peabody Museum Bulletins. 1, 1-137.

[15] AOAC. 2000. Official Methods of Analysis of AOAC International. $1^{\text {th }}$ Ed., AOAC International, Maryland, USA.

[16] Baumel JJ., King SA., Breasile JE., Evans HE., Berge JCV. 1993. Nomina Anatomica Avium. 2nd edition, prepared by the international committee on avian anatomical nomenclature, A Committee of The World Association of Veterinary Anatomists. Nuttall Ornithological Club. Cambridge, Massachusetts.

[17] Rath NC., Balog JM., Huff WE., Huff GR., Kulkarni GB., Tierce JF. 1999. Comparative difference in the composition and biomechanical properties of tibiae of seven-and seventytwo-week-old male and female broiler breeder chickens. Journal of Poultry Science. 78, 1232-9.

[18] Williams B., Waddington D., Solomon S., Thorp B., Farquharson C. 2000. Skeletal development in the meat-type chicken. British Poultry Science, 41, 141-149, 2000.

[19] Alfonso-Torres KA., Gargaglioni LH., Pizauro JM., Faria Filho DE., Furlan RL., Macari M. 2009. Breeder age and bone development in broiler chicken embryos. Arquivo Brasileiro De Medicina Veterinaria Zootecnia, 61, 219-226.

[20] Farquharson C and Jefferies D. 2000. Chondrocytes and longitudinal bone growth: the development of tibial dyschondroplasia. Poultry Science, 79, 994-1004.

[21] Magnusson P., Larsson L., Magnusson M., Davie MWJ., Sharp CA. 1999. Isoforms of bone alkaline phosphatase: Characterization and origin in human trabecular and cortical bone. Journal of Bone and Mineral Research, 14, 1926-33.

[22] Risteli L and Risteli J. 1993. Biochemical markers of bone metabolism. Annals of Medicine, 25, 385-393.

[23] Safaeikatouli M., Jafariahangari Y., Baharlouei A. 2011. An Evaluation on the Effects of Dietary Kaolin and Zeolite on Broilers Blood Parameters, T4, TSH and Growth Hormones. Pakistan Journal of Nutrition, 10, 233-237. 
[24] Elliot MA and Edwards HM. 1991. Comparison of the Effects of Synthetic and Natural Zeolite on Laying Hen and Broiler Chicken Performance. Poultry Science, 70, 2115-30.

[25] Rabon HW., Roland DA., Bryant MM., Robert SC., Barnes DG., Lurent SM. 1995. Absorbtion of Silicon and Aluminum by Hens Fed Sodium Zeolite A with Various Levels of Dietary Cholecalciferol. Poultry Science, 74, 352-359.

[26] Schiano A., Eisinger F., Detolle P., Laponche AM., Brisou B., Eisinger J. 1979. Silicon, bone tissue and immunity. Revue du Rhumatisme et Maladies Osteoarticularies, 46, 483-486.

[27] Brady MC, Dobson PRM, Thavarajah M, Kanis JA. 1991. Zeolite A stimulates proliferation and protein synthesis in human osteoblast-like cells and the osteosarcoma cell line MG 63. Journal of Bone and Mineral Research, 6: 39.

[28] Carlisle EM. 1972. Silicon: an essential element for the chick. Science, 178, 619.

[29] Carlisle EM. 1986. Silicon as an essential trace element in animal nutrition. In: Evered, D., O'Connor, M., editors. Silicon Biochemistry Ciba Foundation Symposium 121. John Wiley and Sons Ltd. Chichester, 123-139.

[30] Schwarz K and Milne DB. 1972. Growth promoting effects of silicon in rats. Nature 239, 333-334.

[31] Carlisle EM. 1976. In vivo requirement for silicon in articular cartilage and connective tissue formation in the chick. Journal of Nutrition, 106, 478-484.

[32] Seaborn CD and Nielsen FH. 2002. Silicon deprivation decreases collagen formation in wounds and bone, and ornithine transaminase enzyme activity in liver. Biological Trace Element Research, 89, 251-261.

[33] Visser JJ and Hoekman K. 1994. Arginine supplementation in the prevention and treatment of osteoporosis. Medical Hypotheses, 43, 339-342.

[34] Hashimoto M., Hitoshi H., Sirisoontorn I., Nakano T., Arita K.,
Tanaka M., Yoshida N. 2013. The effect of bone morphometric changes on orthodontic tooth movement in an osteoporotic animal model. Angle Orthodontist, 83, 776-83.

[35] Pederson L., Kremer M., Judd J., Pascoe D., Spelsberg TC., Riggs BL., Oursler MO. 1999. Androgens regulate bone resorption activity of isolated osteolasts in vitro. Proceding of the National Academy of Science, 96, 505-516.

[36] Kocabagli N. 2001. The effect of dietary phytase supplementation at different levels on tibial bone characteristics and strength in broilers. Turkish Journal of Veterinary and Animal Science, 25, 797-802.

[37] Neumann J. 1986. Changes in bone tissue of broilers treated with growth promoters. Acta Veterinaria Brno, 55, 285-291.

[38] Buckner GD., Insko WMJ., Harms A., Wachs EF. 1950. The comparative rates of growth and calcification of the femur, tibia and metatarsus bones of the male and female New Hampshire chicken having straight keel. Poultry Science, 29, 332-335.

[39] Jendral MJ., Korver DR., Church JS., Feddes JJR. 2008. Bone mineral density and breaking strength of White Leghorns housed in conventional, modified, and commercially available colony battery cages. Poultry Science, 87, 828-837.

[40] Lilburn MS. 1994. Skeletal growth of commercial poultry species. Poultry Science, 73, 897-903.

[41] Norman AW and Hurwitz S. 1993. The role of the vitamin D endocrine system in avian bone biology. Journal of Nutrition, $123,310-316$.

[42] Applegate TJ and Lilburn MS. 2002. Growth of the femur and tibia of a commercial broiler line. Poultry Science, 81, 1289 1294.

[43] Dibner JJ., Richards JD., Kitchell ML., Quiroz MA. 2007. Metabolic challenges and early bone development. Journal of Applied Poultry Research, 16, 126-137. 